ORIGINAL ARTICLE

\title{
Attachment styles and anxiety of rejecters in intimate relationships
}

\author{
Eugenia Mandal A,B,C,D,E,F,G, Anna Latusek ${ }^{A, B, C, D, E, F, G}$ \\ Institute of Psychology, University of Silesia, Katowice, Poland
}

\section{BACKGROUND}

In this paper, the problem of the lack of stability of intimate female-male relationships, the intensity of which is currently increasing, is presented. Attention is focused on early-childhood attachment styles and anxiety in rejecters in intimate relationships.

\section{PARTICIPANTS AND PROCEDURE}

The research included 120 individuals: 60 individuals who had dropped 3-15 partners (on average, $M=3.77$ partners) and 60 individuals from the control group. The following research tools were applied: the Attachment Styles Inventory, and the State-Trait Anxiety Inventory (STAI).

\section{RESULTS}

The results showed that rejecters in intimate relationships obtained higher results than individuals from the control group in an avoidant and an anxious-ambivalent attachment style, and lower ones in a secure attachment style, as well as higher ones in anxiety as a trait. Sex itself was not a differentiating factor in any of the studied variables. An avoidant attachment style, and anxiety as a trait, were predictors of being a rejecter.

\section{CONCLUSIONS}

The obtained results confirm the fundamental findings of the theory of attachment indicating that the lower the level of a secure style is, the lower is the level of interpersonal skills.

\section{KEY WORDS}

dropping a partner; dissolution of an intimate relationship; anxiety; attachment styles

Corresponding Author - Prof. Eugenia Mandal, Institute of Psychology, University of Silesia, 53 Grażyńskiego Str., 40-126 Katowice, Poland, e-mail: eugenia.mandal@us.edu.pl

aUthors' CONTRibution - A: Study design - B: Data collection · C: Statistical analysis · D: Data interpretation . E: Manuscript preparation · F: Literature search · G: Funds collection

TO CITE THIS ARTICLE - Mandal, E., \& Latusek, A. (2014). Attachment styles and anxiety of rejecters in intimate relationships. Current Issues in Personality Psychology, 2(4), 185-195.

RECEIVED 10.10.2014 · REVIEWED 25.10.2014 · ACCEPTED : 01.12.2014 · PUBLISHED 19.12.2014 


\section{BACKGROUND}

In our times, the lack of a stable intimate relationship is becoming a more and more frequent problem in female-male relationships. Simultaneously, intimate relationships between females and males are less and less stable, and the decisions concerning the dissolution of them are taken ever more frequently and rapidly, sometimes even very hastily. Psychologists (Perilloux \& Buss, 2008) report that as many as $85 \%$ of the population have experienced at least one case of dissolution of an intimate romantic relationship during their lives. Global statistical data show that the number of married couples, which, until recently, were considered to be the intimate interpersonal relationships with the longest existence periods, who decide to divorce, is increasing very rapidly. In the year 2002, 45414 divorce court decisions became final, and in 2012 the number increased by nearly 50\%, amounting to 64422 (Central Statistical Office, Poland, 2012).

The analysis of the dynamics of the phases of romantic relationships indicates that the dissolution of a relationship is the final stage that may be entered by a couple of individuals living in an intimate relationship (Sternberg, 2007; Wojciszke, 2002). The dissolution of an intimate relationship usually occurs at the moment at which one of the partners notices that the losses which are suffered by them in that relationship exceed the benefits gained from that (Buss, 2007). Simultaneously, it is possible to observe that there exist individuals who are always the first to initiate the process of dissolution of intimate relationships by the dropping of successive partners, or by obtaining divorces from successive spouses several times. That happens in spite of numerous psychological costs which are borne by those individuals, and by their close relations, as the result of a parting (Rhoades, Kamp Dush, Atkins, Stanley, \& Markman, 2011).

Amongst the potential causes of the dissolution of intimate female-male relationships, various factors are indicated. One group of determinants consists of socio-demographic factors, the most frequent of which include: differences in the level of education between the partners, a low level of income and unemployment. The role of upbringing and the history of the family are both emphasized, when there are conflicts between parents, and, as a consequence, frequently occurring divorces, which increase the probability of the relationships between children who were brought up in such households being unstable and threatened with dissolution, and being afflicted by violence (Amato, 2010; Fletcher, Simpson, Campbell, \& Overall, 2013). Intrapersonal factors increasing the probability of dissolution of a relationship are: adultery of partners, poor communication, different values, and a lack of support and mutual trust. Others include: a sense of restriction of autonomy, disloyalty, the disappearance of romanticism and becoming bored (Baxter, 1986; Nęcki, 1996). Additionally, partners may decide to terminate their relationship when they observe attractive alternatives and the possibility of formation of a relationship with a new partner (Buss, 2007).

In the situation of the dissolution of intimate relationships, different emotions are experienced: resentment, anxiety, remorse and pangs of conscience. Rejecters who are in intimate relationships experience a certain kind of joy in the situations of parting, while simultaneously feeling guilty due to the fact of leaving their partner. Female rejecters experience, in connection with a parting, most frequently sadness, embarrassment and fear, whereas males are frequently observed to become disinterested in the situation, or to be contented (Perilloux \& Buss, 2008).

In the analysis of a difficulty observed in the case of certain individuals and related to the formation of an intimate and stable relationship, an attachment style may be revealed to be of extreme importance. The ways in which an individual is, or becomes, attached, determines the specific character of the establishment of contacts with other individuals by them. A child transfers the learned kind of relationships with their caregiver onto their entire social environment, and the attachment styles that are acquired in the period of childhood in relationships with their parents are reflected in relationships with other individuals in the period of adult life (Ainsworth, Blehar, Waters, \& Wall, 1978; Bowlby, 1969, 2007; Shaver \& Mikulincer, 2009).

Different attachment styles - a secure style, an anxious-ambivalent one, and an avoidant one - result in a number of consequences in the course of entering interpersonal relationships. Those styles manifest different profiles concerning the varied level of intimacy, dependence, separation anxiety, and the confidence that the relationship will be a stable one.

A secure attachment style is the most adaptable attachment style. Individuals attached in that way are capable of entering relationships of all kinds with boldness. They are capable of accepting the fact that they are dependent upon others, as well as the fact of the dependence of others upon themselves. They are capable of forming relationships without being anxious that they will be dropped. They are quite unlikely to be afraid of commitment, and their feelings are stable. Individuals characterized by a secure attachment style describe their relationships as filled with warmth, a major feature of which is a strong feeling of being supported. They also presume that there exists the possibility of maintenance of an intimate romantic relationship for an extended period of time. A secure attachment style is the most frequently encountered style, among both children and adults (Shaver \& Mikulincer, 2007). 
Individuals characterized by an avoidant attachment style, contrary to the individuals attached in a secure way, are afraid of such a relationship. They avoid people who want to form a more intimate relationship with them. They are afraid of relying, and being dependent, upon their partner, whereas, simultaneously, they want to be capable of losing their own independence. They are quite reluctant to believe in true love, and the possibility of maintenance of a long-standing relationship. They are afraid of being hurt, which, as a consequence, makes them avoid intimacy with their partner (Shaver \& Mikulincer, 2007). Due to their reluctance to confront problems, conflicts arising in their relationships frequently remain unsolved, the consequence of which is a decrease in satisfaction with their relationship, and that may lead to a parting (Scharfe \& Bartholomew, 1995).

Individuals characterized by an ambivalent (anxious) attachment style describe their relationships as extremely violent, with a lot of jealousy, lack self-confidence and are afraid of a parting. It is thought that individuals attached in an anxious way may enter this same relationship several times, deciding to dissolve the relationship with the partner then returning to them (Kirkpatrick \& Hazan, 1994). Mario Mikulincer et al. (2010) claim that anxious individuals manifest ambivalence concerning intimacy, and that they keep approaching others and avoiding them all the time. Contrastive aspirations are manifested in them - on the one hand, they are afraid of loneliness and maintain a relationship regardless of the costs of doing so, and, on the other hand, acting under the influence exerted upon them by an impulse, they withdraw from an intimate relationship (Feeney \& Collins, 2001).

The differences between individuals characterized by a particular attachment style are also manifested in the ways in which those individuals react to situations connected with danger. Individuals attached in a secure way in situations of danger attempt to deal with emotions in a constructive way (Mikulincer \& Shaver, 2004; Shaver \& Mikulincer, 2014). The level of anxiety accompanying those emotions is usually lower in the case of those individuals, and they keep their minds open, thanks to which actions regulating their emotions in an intimate relationship are effective (Mikulincer, Shaver, \& Avihou-Kanza, 2011). Individuals characterized by an avoidant style, because of earlier experiences of uncertainty with significant others (attachment figures), in a situation of danger resort to deactivating strategies, consisting in undertaking independent actions aiming at the reduction of danger and the state of anxiety (Mikulincer et al., 2011). They make attempts to minimize the effect and damage which may be caused by the stressor rapidly, i.e. resort to quick self-protective action. Not infrequently, the quickest and most effective action is escaping from a disturbing situation (Shaver \& Mikulincer, 2007).
The style of coping with a threatening situation in the case of individuals characterized by an anxious-ambivalent style is different. Those individuals make attempts in the scope of hyperactivating strategies. They do not attempt sudden actions, whereas they increase their vigilance, and also inform others about the existing danger. They are unlikely to address others with a request for help in coping with a problem (Shaver \& Mikulincer, 2007; Ein-Dor, Mikulincer, \& Shaver, 2011), whereas they tend to increase intimacy with an individual with whom they are in an intimate relationship, not being confident that they will receive support and love from the latter (Mikulincer et al., 2011).

The majority of individuals - women and men are characterized by a secure attachment style (Hazan \& Shaver, 1987; Del Giudice, 2011). However, there exist certain gender differences in terms of an attitude to intimate relationships. Jackson and Kirkpatrick (2007) draw attention to differences in approach to romantic relationships. Men tend to be short-term oriented more frequently than women (Schmitt, 2005). In turn, women, due to the fact that they bear higher costs connected with becoming involved in a relationship than men (Geary, 2005), are more inclined towards long-term relationships, are reluctant to bear risks in an intimate relationship, and are more anxious than men (Del Giudice, 2011). Social expectations towards women and men in that scope are also different; it is expected of women that relationships will be long-term ones, and there is more acceptance for forming short-term relationships in the case of men. It may be presumed that, in the perspective of evolution, avoiding intimacy is a male, rather than female, trait because it is connected with reducing involvement and smaller 'parental' investments. In turn, anxious-ambivalent behaviours, connected with increasing intimacy in order to protect the investments already made and connected with, for example, the upbringing of offspring, are more typical in the case of women (Jackson \& Kirkpatrick, 2007).

In the analysis of the phenomenon of the dropping of partners, it may be revealed that anxiety is of importance (Endler, 1975; Davis, Shaver, \& Vernon, 2003). In our times, in everyday life, it is possible to come across a lot of discussions devoted to the question why it is so difficult to maintain a stable relationship in popular literature. The majority of widespread opinions indicate that anxiety is the chief cause of the dissolution of intimate relationships. Amongst popular opinions, the dominant view is that the reason for the dissolution of numerous intimate relationships is anxiety in connection with a possible loss of one's own private space, intimacy anxiety, anxiety in connection with a possible loss of independence, and the lack of certainty concerning being accepted by the partner. The research conducted to date and concern- 
ing anxiety in intimate relationships suggests that it is most frequently manifested in the form of being anxious about intimacy with a partner. Anxiety is a negative correlate both of the duration of an intimate relationship and of the number of long-term relationships (Descutner \& Thelen, 1991).

Anxiety and fear are inseparably connected with the functioning of a human being, and they are significant in biological terms. Fear is a response to a danger, whereas anxiety is irrational. The source of anxiety is situated in childhood and the lack of the feeling of safety in the relationship with parents. The repressed hostility towards one's parents makes one feel unworthy of love, and generates anxiety related to possible relationships. Amongst the ways of combating anxiety, withdrawal from interpersonal relationships is mentioned (Horney, 1937). Charles Spielberger (1970) draws attention to the two kinds of anxiety: anxiety as a state, and anxiety as a trait. Anxiety as a state is a situation-elevated level of anxiety, whereas anxiety as a trait is defined as a motive or a behavioural disposition acquired in childhood, consisting in the experiencing of objectively safe situations as dangerous.

Fear is applied for recognizing a danger - either a biological or a social one. It has a predictive function, and it is in connection with events which may occur in the future. It occurs in situations of danger, or an anticipated negative assessment (Eysenck, Derakshan, Santos, \& Calvo, 2007). Antoni Kępiński (2002) points out that if a subject fails to follow the suggestion that they should flee, there will be two choices left to them: either destroy the danger, or end up being destroyed themselves. Additionally, anxiety may represent negative emotionality - neuroticism in the meaning assigned to it by Eysenck (1947), which is composed of anxiety, feeling guilty, tension, being depressed and a low level of self-esteem.

The objective of our present research was to verify the level of attachment styles and the exacerbation of anxiety in the case of rejecters in intimate relationships, and also whether in the scope of those profiles rejecters differ from individuals not dropping partners. Until now, to the best of our knowledge, no research into the personal profiles of rejecters in intimate relationships has been conducted.

\section{AIMS AND HYPOTHESES}

The objective of the research was to describe personal profiles - in the scope of anxiety as a trait, as well as the level of separate attachment styles - of rejecters in intimate relationships. It was verified whether individuals frequently dropping partners differ from the individuals from the control group - individuals who do not drop partners.
The following hypotheses were proposed:

1. There exist differences between rejecters and individuals from the control group in terms of attachment styles. Rejecters obtain higher results in an avoidant and ambivalent style, and lower results in a secure style.

2. There exist differences between rejecters and individuals from the control group in terms of anxiety as a trait. A major feature of rejecters is a higher level of anxiety as a trait than is observed in the case of individuals capable of maintaining a stable relationship.

3. An avoidant attachment style, ambivalent attachment style and severe anxiety (as a trait) are the predictors of being a rejecter.

4. There are differences in the scope of anxiety and an attachment style between rejecters and individuals from the control group in connection with biological sex. In the case of males, those differences are greater.

5. There exists a correlation between the number of dropped partners and attachment styles. The larger the number of dropped partners in the case of a studied individual, the higher is the level of an avoidant attachment style, and the lower is the level of a secure attachment style, observed as a major feature of the studied individual.

6. There exists a correlation between the number of dropped partners and anxiety as a trait. The higher the level of the result in the scope of anxiety as a trait, the greater the number of dropped partners. 7. The frequency of dropping (the number of dropped partners) is not associated with sex.

\section{PARTICIPANTS AND PROCEDURE}

\section{PARTICIPANTS}

The research was conducted amongst the students of several Silesian institutions of tertiary education (the University of Silesia, the University of Economics, the Academy of Physical Education and the Medical University of Silesia), and also other adult individuals who had expressed their willingness to participate in the research. The method of selection of the studied individuals was the snowball procedure.

In the research, the studied individuals declared whether they currently had been in an intimate relationship for a period of time no shorter than one year, shorter than one year, or not at all. Furthermore, they were requested to describe themselves precisely as an individual who was 'dropping' or 'not dropping' their partners in intimate relationships. Furthermore, the studied individuals drew up the balance of their intimate relationships, which means, they determined how many times they had dropped their partners, and also had been dropped by them. 
In the group of 'rejecters', individuals who described themselves as 'dropping' their partners, and also declared that they currently were not in a stable intimate relationship, or that they had been in one for a period shorter than one year, were included. The control group comprised those individuals who described themselves as 'not dropping' their partners and also pointed out that they had currently been in a stable intimate relationship that had existed for a period longer than one year. The procedure of selection for the study group was identical to the research procedure concerning rejecters in intimate relationships applied by Carin Perriloux, and by David Buss (2008).

The procedure of selection for the study group or the control group was provided with the rationale in the form of the data obtained in the course of the research which show that the first year of a relationship is a critical period for the development of an intimate relationship (Buss \& Shackelford, 1997; Fletcher, Simpson, \& Thomas, 2000). An individual who has managed to remain in a relationship beyond the critical period (the first year of a relationship) is capable of building a stable intimate relationship with another individual regardless of the history of their own previous experiences in relationships and their own age. In the American literature, female-male intimate relationships which have existed for more than one year are already treated as long-term relationships (Fletcher et al., 2000).

One hundred and twenty individuals were included in the research. The group of rejecters comprised 60 individuals: 30 females and 30 males. The control group was also composed of 60 individuals: 30 females and 30 males. The average age of the studied individuals was 24.20 years $(S D=4.18)$. The average age of the individuals dropping partners was $M=23.27$, whereas that of individuals from the control group was $M=25.16$. Both groups included individuals who had completed secondary education (51\%) and tertiary education (49\%). The individuals included in the study group dropped, on average, 4 partners $(M=3.77$, $S D=2.68)$; the minimum was 3 , the maximum 15 . The difference between the number of dropped partners in individuals from the study group and those from the control group was statistically significant $(p<.001)$, which confirmed the justifiability of the division of the studied individuals into the group of 'rejecters' and the control group.

\section{RESEARCH MEASURES}

The Attachment Styles Inventory of Mirosław Plopa (2008) is applied for research into the level of attachment styles. It is composed of three scales: of a secure style, an anxious-ambivalent style, and an avoidant one. Each of those scales is composed of 8 items. The studied individual assesses (with the application of the scale from 1 to 7 ) the degree to which a given statement describes themselves, where 1 means 'I definitely do not agree', and 7 means 'I definitely agree'. A major feature of the tool is high reliability ratios: the reliability of the scale for a secure style is $\alpha=.91$ (.85 in our research), for an anxious style $\alpha=.78$ (.85 in our research), and for an avoidant style $\alpha=.80$ (.84 in our research). In the calculation of the results, the procedure of classification for a given attachment style is not conducted; instead, the studied individuals obtain a given number of points in each of the three attachment styles. Attachment styles are interval variables.

The State-Trait Anxiety Inventory (STAI) (Spielberger, Gorsuch, \& Lushene, 1970) in the Polish adaptation (Spielberger, Strelau, Tysarczyk, \& Wrześniewski, 1987) has been used. This inventory is composed of two scales, each of which has 20 items, investigating anxiety as a state and anxiety as a trait. The studied individual answers with the application of the scale from 1 to 4 , where 1 means 'hardly ever', and 4 means 'nearly always'. The internal compatibility of both of the scales is high (from .84 to .94), and a similar result was obtained for absolute stability (.79). The reliability of this inventory in the conducted research was $\alpha=.87$. In the present research, the results obtained with the application of the scale of anxiety as a trait were applied.

\section{RESULTS}

The analysis of the obtained results showed that rejecters in intimate relationships exhibited a secure attachment style most intensively $(M=39.25, S D=7.91)$, whereas an anxious-ambivalent style was exhibited by them less intensively $(M=28.98, S D=7.21)$, and an avoidant style least intensively $(M=24.33, S D=8.04)$. The level of anxiety in the case of rejecters was $M=43.05(S D=8.65)$. The individuals from the control group most intensively exhibited a secure attachment style $(M=47.22, S D=7.76)$, less intensively an anxious-ambivalent one $(M=23.37, S D=10.76)$, and least intensively an avoidant one $(M=15.00, S D=6.38)$. The degree of anxiety as a trait in the case of individuals from the control group was $M=38.78(S D=9.09)$.

In order to verify the hypothesis claiming that there exist differences between individuals dropping their partners and individuals from the control group in terms of attachment styles, Student's $t$-test was conducted. The analysis of the differences showed that the group of rejecters was significantly different in terms of statistics from the control group as far as the studied variables are concerned. A major feature of rejecters was a significantly lower level of a secure attachment style $(M=39.25)$ than that in the case of individuals from the control group $(M=47.22$, $p<.001)$. In the scope of an avoidant style, rejecters 
Table 1

Anxiety as a trait and attachment styles. Comparison of mean values in the group of rejecters and the control group

\begin{tabular}{|c|c|c|c|c|c|c|c|}
\hline \multirow[t]{2}{*}{ Variable } & \multicolumn{2}{|c|}{ Rejecters } & \multicolumn{2}{|c|}{ Control group } & \multirow[t]{2}{*}{$t$} & \multirow[t]{2}{*}{$p$} & \multirow[t]{2}{*}{$d$} \\
\hline & $M$ & $S D$ & $M$ & $S D$ & & & \\
\hline Secure style & 39.25 & 7.92 & 47.22 & 7.76 & -5.57 & $<.001$ & 1.02 \\
\hline Avoidant style & 24.33 & 7.04 & 15.00 & 6.38 & 7.04 & $<.001$ & 1.39 \\
\hline Anxious-ambivalent style & 28.98 & 7.21 & 23.37 & 10.76 & 3.36 & .001 & 0.61 \\
\hline Anxiety as a trait & 43.05 & 8.65 & 38.78 & 9.09 & 2.63 & .009 & 0.48 \\
\hline
\end{tabular}

Table 2

Anxiety as a trait and attachment styles. Comparison of mean values in the group of female rejecters and the control group of females

\begin{tabular}{|c|c|c|c|c|c|c|c|}
\hline \multirow[t]{2}{*}{ Variable } & \multicolumn{2}{|c|}{$\begin{array}{l}\text { Females dropping } \\
\text { male partners }\end{array}$} & \multicolumn{2}{|c|}{$\begin{array}{c}\text { Females } \\
- \text { control group }\end{array}$} & \multirow[t]{2}{*}{$t$} & \multirow[t]{2}{*}{$p$} & \multirow[t]{2}{*}{$d$} \\
\hline & $M$ & $S D$ & $M$ & $S D$ & & & \\
\hline Secure style & 39.47 & 9.13 & 48.93 & 3.99 & 5.20 & $<.001$ & 1.34 \\
\hline Avoidant style & 24.27 & 9.05 & 15.10 & 5.66 & -4.70 & $<.001$ & 1.21 \\
\hline Anxious-ambivalent style & 28.53 & 8.03 & 24.87 & 10.90 & -1.48 & .143 & 0.38 \\
\hline Anxiety as a trait & 41.57 & 7.44 & 41.20 & 9.61 & -0.17 & .869 & 0.04 \\
\hline
\end{tabular}

$(M=24.33)$ obtained significantly higher results than individuals who were in a stable relationship $(M=15.00$, $p<.001)$. In an anxious-ambivalent style, rejecters obtained higher results $(M=28.98)$ than individuals from the control group $(M=23.37, p<.001)$. Rejecters also obtained higher results $(M=43.05)$ in the scope of anxiety as a trait than individuals from the control group $(M=38.78, p=.009)$. The mode was situated in the range between $d=0.48$ in the scope of anxiety and $d=1.39$ in an avoidant attachment style. Differences between rejecters and individuals from the control group were found for all the studied variables, and their major feature was a very large effect size (see Table 1).

We also tested the hypothesis that the differences in terms of anxiety and attachment style between individuals dropping partners and individuals from the control group are connected with gender. The analysis in the group of studied females indicated that female rejecters in intimate relationships obtained lower results in the scope of a secure attachment style $(M=39.47)$ than the females from the control group $(M=48.93, p<.001)$. A major feature of female rejecters was a significantly higher level of an avoidant attachment style $(M=24.27)$ than that in the case of females from the control group $(M=15.10, p<.001)$, whereas in the group of females no significant differences in the scope of an anxious-ambivalent attachment style $(p=.143)$, nor in that of anxiety as a trait $(p=.869)$, were found (see Table 2). The strongest effect size was observed in a secure $(d=1.34)$ and also in an avoidant attachment style $(d=1.21)$.
The results showed that males $(M=39.03)$ dropping partners in intimate relationships obtained lower results in the scope of a secure attachment style than males $(M=45.50)$ from the control group $(p<.001)$. A major feature of the former was a higher level of an avoidant attachment style $(M=24.40)$ than that observed in the case of males $(M=14.90$, $p<.001)$ from the control group. Both in the scope of an anxious-ambivalent attachment style and in that of anxiety as a trait, males significantly differed from one another. Make rejecters obtained higher results in an anxious-ambivalent attachment style $(M=29.43)$ than males from the control group $(M=21.87, p=.001)$. Furthermore, male rejecters obtained higher results $(M=44.53)$ than male individuals from the control group $(M=36.37, p<.001)$ in the scope of anxiety as a trait. A feature of all the differences was a very large effect size, from $d=0.93$ in anxiety to $d=1.34$ in an avoidant attachment style (see Table 3).

In the analysis of the results, a multi-dimensional analysis of variance (MANOVA) in the pattern $2(\operatorname{sex}) \times 2$ (rejecters versus individuals from the control group) was conducted. It was proved that rejecters were significantly different from individuals from the control group in terms of studied variables (Wilks' $\lambda=.69 ; F(4,113)=12.92, p<.001$, partial $\left.\eta^{2}=.31\right)$. The females and males from the entire sample were not significantly different (Wilks' $\lambda=.97, F(4,113)=0.88$; $p<.476$, partial $\eta^{2}=.03$ ), whereas the interaction between sex and classification into the group of reject- 
Table 3

Anxiety as a trait and attachment styles. Comparison of mean values in the group of male rejecters and the control group of males

\begin{tabular}{|c|c|c|c|c|c|c|c|}
\hline \multirow[t]{2}{*}{ Variable } & \multicolumn{2}{|c|}{$\begin{array}{l}\text { Males dropping } \\
\text { female partners }\end{array}$} & \multicolumn{2}{|c|}{$\begin{array}{c}\text { Males } \\
- \text { control group }\end{array}$} & \multirow[t]{2}{*}{$t$} & \multirow[t]{2}{*}{$p$} & \multirow[t]{2}{*}{$d$} \\
\hline & $M$ & $S D$ & M & $S D$ & & & \\
\hline Secure style & 39.03 & 6.65 & 45.50 & 10.07 & 2.94 & .001 & 0.76 \\
\hline Avoidant style & 24.40 & 7.05 & 14.90 & 7.12 & -5.19 & $<.001$ & 1.34 \\
\hline Anxious-ambivalent style & 29.43 & 6.39 & 21.87 & 10.58 & -3.35 & .001 & 0.87 \\
\hline Anxiety as a trait & 44.53 & 9.61 & 36.34 & 7.99 & -3.58 & $<.001$ & 0.93 \\
\hline
\end{tabular}

Table 4

Anxiety as a trait and attachment styles. Results of one-way analyses of variance in the pattern 2 (sex) $\times 2$ (dropping individual versus the control group)

\begin{tabular}{|c|c|c|c|}
\hline & $F(1,116)$ & $p$ & $\eta^{2}$ \\
\hline \multicolumn{4}{|l|}{ DV: Anxiety as a trait } \\
\hline Sex & 0.34 & .559 & .05 \\
\hline Rejecters versus control group & 7.19 & .008 & .34 \\
\hline Interaction & 6.00 & .016 & .06 \\
\hline \multicolumn{4}{|l|}{ DV: Secure style } \\
\hline Sex & 1.83 & .178 & .02 \\
\hline Rejecters versus control group & 31.22 & $<.001$ & .21 \\
\hline Interaction & 1.11 & .295 & .01 \\
\hline \multicolumn{4}{|l|}{ DV: Avoidant style } \\
\hline Sex & $<.01$ & .980 & $<.01$ \\
\hline Rejecters versus control group & 48.78 & $<.001$ & .30 \\
\hline Interaction & 0.02 & .901 & $<.01$ \\
\hline \multicolumn{4}{|l|}{ DV: Anxious-ambivalent style } \\
\hline Sex & 0.40 & .532 & $<.01$ \\
\hline Dropping individuals versus control group & 11.26 & .001 & .09 \\
\hline Interaction & 1.36 & .246 & .01 \\
\hline
\end{tabular}

ers or the control group was revealed to be significant exclusively at the level of a statistical trend [not significant] (Wilks' $\lambda=.93 ; F(4,113)=2.19, p<.075$, partial $\left.\eta^{2}=.07\right)$ (see Table 4 ).

The one-way analyses confirmed that rejecters were different from individuals from the control group in terms of attachment styles, and also in that of anxiety as a trait (anxiety as a trait, $p=.008$; a secure style $p<.001$; an avoidant style, $p<.001$; an anxious-ambivalent style, $p=.001$ ). Sex itself was not a differentiating factor in any of the studied variables (anxiety as a trait, $p=.559$; a secure style $p=.178$; an avoidant style, $p=.980$; an anxious-ambivalent style, $p=.532$ ). An interaction between sex and being a re- jecter, or, alternatively, an individual from the control group, was found exclusively in the scope of anxiety as a trait $(p=.016)$ (see Table 4$)$.

The conducted logistic regression analysis showed that, amongst the studied variables, the strongest predictor of being a rejecter was the level of an avoidant attachment style (Wald $\chi^{2}=10.11, p=.001$; odds ratio $(O R)>1.00)$. In that case, the odds ratio was 1.15 , which means that an avoidant style may be considered to be a predictor of being a rejecter. The results of the logistic regression analysis indicated that anxiety as a trait was also a significant predictor of dropping (Wald $\chi^{2}=6.34, p=.012, O R>1.00$ ). It was proved that a secure (Wald $\chi^{2}=2.29, p=.130$, 
Table 5

Anxiety as a trait and attachment styles. Recapitulation of results of the logistic regression analysis

\begin{tabular}{ccccc}
\hline & Secure & Anxious-ambivalent style & Avoidant style & Anxiety as a trait \\
\hline Assessment & -.53 & .02 & .14 & .06 \\
Standard error & .04 & .03 & .04 & .02 \\
$t(116)$ & -1.51 & 0.99 & 3.18 & .52 \\
$p$ & .133 & .327 & .001 & .013 \\
$-95 \% \mathrm{CL}$ & -0.12 & -0.02 & 0.05 & 0.01 \\
$+95 \% \mathrm{CL}$ & 0.02 & 0.07 & 0.23 & 0.09 \\
Wald $\chi^{2}$ & 2.29 & 0.97 & 10.11 & 6.34 \\
$p$ & .130 & .325 & .001 & .012 \\
Odds ratio with unit & 0.95 & .1 .03 & 1.15 & 1.06 \\
$-95 \% \mathrm{CL}$ & 0.88 & 0.98 & 1.05 & 1.01 \\
$+95 \% \mathrm{CL}$ & 1.02 & 1.08 & 1.25 & 1.10 \\
Scope of odds ratio & 0.09 & 3.04 & 202.79 & 10.48 \\
-95\% CL & 0.01 & 0.32 & 7.41 & 1.65 \\
$+95 \% \mathrm{CL}$ & 2.09 & 28.53 & 5549.87 & 66.47 \\
\hline
\end{tabular}

$O R<1.00)$ and an anxious-ambivalent attachment style (Wald $\chi^{2}=0.97, p=.325, O R>1.00$ ) were not statistically significant predictors of being a rejecter. With the application of the classification of cases, the correct selection of the sample for $75.83 \%$ of cases (see Table 5) was confirmed.

An analysis of the correlations between the number of partners dropped by the studied individuals and the studied variables was also conducted. The results showed a negative correlation (Spearman's $r h o=-.40, p<.001$ ) between the number of partners dropped by the studied individuals and a secure attachment style, and a positive one between the number of dropped partners and an avoidant attachment style (Spearman's rho $=.38 ; p<.001$ ). The females dropped, on average, $M=2.83(S D=2.54)$ partners, whereas males dropped, on average, $M=2.80$ $(S D=2.41)$ female partners $(p=.941)$. This difference was not statistically significant.

\section{DISCUSSION}

The research and analyses presented in this paper attempted to study the problem of the determinants of the phenomenon of dropping in intimate relationships in the context of selected predisposition properties of rejecters.

The results showed that an avoidant attachment style is the strongest predictor of being a rejecter.
Rejecters seem to avoid intimate female-male relationships. The dropping of a partner may be treated as a specific escape from an intimate relationship. In that way, rejecters avoid intimacy with a partner, or dependence upon them (Shaver \& Mikulincer, 2007). Individuals characterized by an avoidant style frequently form relationships in which intimacy, being one of the fundamental components of love (Sternberg, 2007), is not present (Plopa, 2003). In turn, the lack of intimacy in a relationship may be a cause of its dissolution.

In the present research, anxiety as a trait was revealed to be a predictor of the dropping of partners in intimate female-male relationships as well. Individuals characterized by relatively high (higher than the individuals from the control group) anxiety as a trait drop partners in intimate relationships more frequently. Probably this is because, due to the experienced anxiety, those individuals are incapable of trusting another individual, and cannot open themselves up to a partner. Such individuals form relationships characterized by a significant emotional distance, are afraid of committing themselves, and are less adjusted to numerous social relationships (Wrześniewski, Sosnowski, Jaworowska, \& Fecenec, 2006). The dropping of their partners may be due to the fear that they themselves would be abandoned and dropped. They prefer to break up successive intimate relationships themselves so as to - as they presume - avoid ending up being dropped by an individ- 
ual with whom they are in an intimate relationship. What may also be significant is anxiety of intimacy developing between the partners, which, as a consequence, may motivate individuals characterized by a high level of anxiety to dissolve a relationship (Descutner \& Thelen, 1991).

In the present research, significant differences were also found in both the scope of anxiety and an anxious-ambivalent attachment style, between rejecters and individuals from the control group. This result may be understood in the perspective of other information indicating that individuals characterized by a high level of anxiety, and those characterized by an anxious-ambivalent style, manifest, as a major feature of themselves, a lowered level of self-esteem and a lack of self-confidence, and that they describe their relationships as filled with jealousy; those individuals do not trust their partner (Shaver \& Mikulincer, 2009). Such traits may cause numerous disturbances in communication in an intimate relationship, misunderstandings, conflicts and arguments, which are not conducive to stability or satisfaction in intimate relationships. This may cause an increased readiness for dropping a partner in an intimate relationship.

Simultaneously, attention should be paid to the fact that an anxious-ambivalent style is not a predictor of being an individual dropping their partner. Perhaps it is caused by the very structure of an anxious-ambivalent style, and alternative tendency and avoidance are of importance here. Individuals attached in an anxious way are usually very jealous, and their relationships are not lasting, but, above all, they are afraid of loneliness and separation from their partner, which may hinder making a decision to leave them (Schachner \& Shaver, 2002).

Although in the analysis of differences between groups a difference between individuals dropping their partners and individuals from the control group in the scope of a secure attachment style was found, a secure attachment style was not ascertained to be a predictor of being an individual dropping their partner, which may be explained by the fact that particular attachment styles are activated in a situation which is, subjectively, threatening for an individual. Individuals whose style of attachment is secure react to problems arising in an intimate relationship in a peaceful way, giving the matter proper consideration. They analyse the situation, and/or discuss the problems and danger with other individuals close to them (Feeney \& Collins, 2001). Hence, a secure attachment style provides time for considering the situation and making a conscious decision concerning staying in a relationship, or separating. However, it does not protect an intimate relationship against dissolution, but exerts an influence on making decisions concerning a parting after more consideration and a more profound analysis of the situation.
The analysis in the perspective of differences between sexes indicated that female rejecters in comparison with females from the control group not dropping partners differ exclusively in the scope of a secure style, and an avoidant one, whereas male rejecters in comparison with males from the control group differ in the scope of all the studied traits. An explanation for the fact that exclusively male rejecters (and not female rejecters) obtain higher results on the scale of anxiety as a trait, and also in an anxious-ambivalent attachment style, may be the fact that experiencing anxiety is frequently treated by society as permitted in the case of females, and as not suitable, or forbidden, in the case of males. As a consequence, it may result in a situation in which males do not admit that they experience anxiety, or, in a situation in which anxiety appears, they feel a strong need to reduce and repress it. In intimate female-male relationships, that may mean the dropping of female partners, which means breaking up an intimate relationship in which anxiety appears.

Differences in the scope of an anxious-ambivalent attachment style in the groups of males, though not amongst females, may be explained by the supposition that a subjectively experienced fear of being dropped by a female partner, constituting the foundation of an anxious-ambivalent attachment style, may be more traumatic for males than for females. The reason is that, in many social groups, a dropped male individual may be perceived as not very masculine, not matching the stereotypical role of a macho, tough cookie and heartbreaker, whereas a dropped female may be perceived positively as matching the stereotype of a frail woman. The reason is that she may evoke compassion, understanding and willingness to provide help. Dropping itself may be perceived as more 'masculine', as connected with 'breaking' female hearts, and therefore may be more accepted, and more willingly undertaken by males. That may be a symptom of willingness to comply with stereotypical expectations concerning male and female gender roles. A failure to comply with social expectations concerning such a role may, in turn, be the source of stress (Kaźmierczak, 2010).

The obtained results confirm the fundamental findings of the theory of attachment indicating that the lower the level of a secure style is, the lower is the level of interpersonal skills (Bowlby, 2007). A low level of such skills may contribute to the lack of satisfactory communication and support between partners and the lack of mutual understanding, lowering the sense of quality of a relationship, and, as a consequence, becoming the cause of the dropping of partners in intimate relationships. The empathy of the partners may also be important (Kaźmierczak, 2013).

The results of the present research show that rejecters in intimate relationships, both females and males, manifest as a major feature of themselves 
a level of a secure attachment style significantly lower than that of individuals from the control group, and the lower the level of a secure style, the greater is the number of dropped partners in intimate relationships. Similarly, female and male rejecters manifested, as a major feature of themselves, a higher level of an avoidant style than that of females and males from the control group, and the higher that level was, the greater was the number of partners dropped by them. Those results are convergent with the results of the present research indicating a predictive role of an avoidant attachment style in the dropping of partners.

In recapitulation, the obtained results show that rejecters manifest, as a major feature of themselves, a lower level of a secure attachment style and elevated indicators of an avoidant attachment style, an anxious-ambivalent attachment style, and also of anxiety as a trait, than the individuals from the control group.

However, it should be remembered that the present research is focused on the selected personal aspects of the functioning of partners in intimate relationships. In the analysis of the phenomenon of dropping, apart from the analysed variables, other tangible, situational, or, alternatively, social-cultural causes of dropping, being in connection with a particular situation of a couple of individuals connected by an intimate relationship, may come to the fore. $\mathrm{Al}-$ though this research does not encompass the entire complicated phenomenon comprising the dynamics of intimate relationships, the results may encourage further analyses of the disturbing, and more and more frequently observed in our times, phenomenon of failure to maintain a stable intimate relationship between females and males.

\section{RefERENCES}

Ainsworth, M., Blehar, M., Waters, E., \&Wall, S. (1978). Patterns of Attachment. A psychological study of the strange situation. Hillsdale, NJ: Erlbaum.

Amato, P. R. (2010). Research on divorce: continuing trends and new developments. Journal of Marriage and Family, 72, 650-666.

Baxter, L. (1986). Gender differences in the heterosexual relationship rules embaded in breakups accounts. Journal of Social and Personal Relationships, 2, 289-306.

Bowlby, J. (2007). Przywiązanie [Attachment]. Warszawa: PWN.

Bowlby, J. (1969). Attachment and Loss. Vol. 1. Attachment. Chatham Kent: PIMLICO.

Buss, D., \& Shackelford, T. K. (1997). Susceptibility to infidelity in the first year of marriage. Journal of Research in Personality, 31, 193-221.

Buss, D. (2007). Ewolucja miłości [The Evolution of Love]. In: R. Sternberg (ed.), Nowa psychologia mi- tości [The New Psychology of Love] (pp. 101-131). Taszów: Biblioteka Moderatora.

Central Statistical Office (2012). Rocznik Demograficzny 2012 [Demographic Yearbook 2012]. Warszawa: Zakład Wydawnictw Statystycznych.

Davis, D., Shaver, P. R., \& Vernon, M. L. (2003). Physical, emotional, and behavioral reactions to breaking up: The roles of gender, age, emotional involvement, and attachment style. Personality and Social Psychology Bulletin, 29, 871-884.

Del Giudice, M. (2011). Sex differences in romantic attachment: A meta-analysis. Personality and Social Psychology Bulletin, 37, 193-214.

Descutner, C. J., \& Thelen, M. H. (1991). Development and validation of a fear-of-intimacy scale. Journal of Consulting and Clinical Psychology, 3, 218-225.

Ein-Dor, T., Mikulincer, M., \& Shaver, P. R. (2011). Attachment insecurities and the processing of threat-related information: studying the schemas involved in insecure people's coping strategies. Journal of Personality and Social Psychology, 101, 78-93. DOI: 10.1037/a0022503.

Endler, N. S. (1975). A person-situation interaction model of anxiety. In: D. C. Spielberger, \& I. G. Sarason (eds.), Stress and anxiety (vol. 1, pp. 145164). Washington, DC: Hemisphere.

Eysenck, H. J. (1947). The structure of human personality. New York: John Wiley and Sons, Inc.

Eysenck, M., Derakshan, N., Santos, R., \& Calvo, M. (2007). Anxiety and cognitive performance: Attentional control theory. Emotion, 7, 336-353.

Feeney, B. C., \& Collins, N. L. (2001). Predictors of caregiving in adult intimate relationships: An attachment theoretical perspective. Journal of Personality and Social Psychology, 80, 972-994.

Fletcher, G. J. O., Simpson, J., \& Thomas, G. (2000). Ideals, perceptions and evaluations in early relationship development. Journal of Personality and Social Psychology, 79, 933-940.

Fletcher, G., Simpson, J., Campbell, L., \& Overall, N. (2013). The Science of Intimate Relationships. New York: Wiley-Blackwell.

Geary, D. C. (2005). Evolution of paternal investment. In: D. M. Buss (ed.), The evolutionary psychology handbook (pp. 483-505). New York, NY: Wiley.

Hazan, C., \& Shaver, P. R. (1987). Romantic love conceptualized as an attachment process. Journal of Personality and Social Psychology, 52, 511-524.

Horney, K. (1937). The Neurotic Personality of Our Time. New York: W. W. Norton, Incorporated.

Jackson, J. J., \& Kirkpatrick, L. A. (2007). The structure and measurement of human mating strategies: Towards a multidimensional model of sociosexuality. Evolution and Human Behavior, 28, 382-391.

Kaźmierczak, M. (2010). The feminine and masculine gender role stress - conclusions from Polish studies. Polish Psychological Bulletin, 41, 20-30. DOI: 10.2478/s10059-010-0003-5. 
Kaźmierczak, M. (2013). Postrzegana empatia partnera jako predyktor satysfakcji z relacji [Perceived partner's empathy as a predictor of satisfaction in relationship]. Psychologia Spoteczna, 8, 435-447.

Kępiński, A. (2002). Lęk [Anxiety]. Kraków: Wydawnictwo Literackie.

Kirkpatrick, L., \& Hazan, C. (1994). Attachment styles and close relationships: A four-year prospective study. Personal Relationships, 1, 123-142.

Mikulincer, M., \& Shaver, P. R. (2004). Security-based self-representations in adulthood: Contents and processes. In: W. S. Rholes, J. A. Simpson (eds.), Adult attachment: Theory, research, and clinical implications (pp. 159-195). New York: Guilford Press.

Mikulincer, M., Shaver, P. R., \& Avihou-Kanza, N. (2011). Individual differences in adult attachment are systematically related to dream narratives. Attachment and Human Development, 13, 105-123.

Mikulincer, M., Shaver, P. R., Bar-On, N., \& Ein-Dor, T. (2010). The pushes and pulls of close relationships: Attachment insecurities and relational ambivalence. Journal of Personality and Social Psychology, 98, 450-468.

Nęcki, Z. (1996). Atrakcyjność wzajemna [The Mutual Attraction]. Kraków: Wydawnictwo Profesjonalnej Szkoły Biznesu.

Perilloux, C., \& Buss, D. (2008). Breaking up romantic relationships: cost experienced and coping strategies deployed. Evolutionary Psychology, 6, 164-181.

Plopa, M. (2003). Rozwój i znaczenie bliskich więzi w życiu człowieka [Development and the importance of close relationships in human life]. In: B. Wojciszke, \& M. Plopa (eds.), Osobowość a procesy psychiczne $i$ zachowanie [Personality and mental processes \& behavior] (pp. 49-79). Krakow: Wydawnictwo Impuls.

Plopa, M. (2008). Kwestionariusz Stylów Przywiazaniowych (KSP). Podręcznik [Attachment Styles Inventory. Textbook]. Warszawa: Pracownia Testów Psychologicznych Polskiego Towarzystwa Psychologicznego.

Rhoades, G. K., Kamp Dush, C. M., Atkins, D. C., Stanley, S. M., \& Markman, H. J. (2011), Breaking up is hard to do: The impact of unmarried relationship dissolution on mental health and life satisfaction. Journal of Family Psychology, 25, 366-374.

Schachner, D. A., \& Shaver, P. R. (2002). Attachment style and human mate poaching. New Review of Social Psychology, 1, 122-129.

Scharfe, E., \& Bartholomew, K. (1995). Accommodation strategies and attachment in young couples. Journal of Social and Personal Relationships, 12, 389-401.

Schmitt, D. P. (2005). Sociosexuality from Argentina to Zimbabwe: A 48-nation study of sex, culture, and strategies of human mating. Behavioral and Brain Sciences, 28, 247-311.
Shaver, P. R., \& Mikulincer, M. (2007). Adult attachment strategies and the regulation of emotion. In: J. J. Gross (ed.), Handbook of emotion regulation (pp. 446-465). New York: Guilford Press.

Shaver, P. R., \& Mikulincer, M. (2014). Adult attachment strategies and the regulation of emotion. In: J. J. Gross (ed.), Handbook of emotion regulation ( $2^{\text {nd }}$ ed., pp. 237-250). New York: Guilford Press.

Shaver, P., \& Mikulincer, M. (2007). Podejście behawiorystyczne do miłości romantycznej. Systemy: przywiązania, opieki i seksualny [A Behavioral Approach to Romantic Love Relationships. Systems: Attachment, Caregiving, and Sex]. In: R. Sternberg, \& K. Weis (eds.), Nowa psychologia miłości [The New Psychology of Love] (pp. 59-100). Taszów: Biblioteka Moderatora.

Shaver, P., \& Mikulincer, M. (2009). What's inside the minds of securely and insecurely attached people? The secure-base script and its associations with attachment-style dimensions. Journal of Personality and Social Psychology, 97, 615-633.

Spielberger, C. D., Gorsuch, R. L., \& Lushene, R. E. (1970). The State-Trait Anxiety Inventory: Test manual. Palo Alto, CA: Consulting Psychologist Press.

Spielberger, C. D., Strelau, J., Tysarczyk, M., \& Wrześniewski, K. (1987). Inwentarz Stanu i Cechy Lęku (ISCL) [State Traite Anxiety Inventory]. Warszawa: Pracownia Testów Psychologicznych Polskiego Towarzystwa Psychologicznego.

Sternberg, R. (2007). Dwuskładnikowa teoria miłości [A Duplex Theory of Love]. In: R. Sternberg, \& K. Weis (eds.), Nowa psychologia mitości [The New Psychology of Love] (pp. 275-296). Taszów: Biblioteka Moderatora.

Sternberg, R., \& Weis, K. (2007). Nowa psychologia miłości [The New Psychology of Love]. Taszów: Biblioteka Moderatora.

Wojciszke, B. (2002). Człowiek wśród ludzi. Zarys psychologii spotecznej [A man among people. Outline of the Social Psychology]. Warszawa: Wydawnictwo Naukowe SCHOLAR.

Wrześniewski, K, Sosnowski, T., Jaworowska, A., \& Fecenec, D. (2006). Inwentarz Stanu i Cechy Lęku STAI [State Traite Anxiety Inventory]. Warszawa: Pracownia Testów Psychologicznych Polskiego Towarzystwa Psychologicznego. 